\title{
Experimental Evaluation of the Effect of Inclination and Dust Deposition on Production Capacity of Photovoltaic Installations in West African Nations: Case Studyin Mali Drame
}

\author{
A. Sidiki ${ }^{1,2 *}$, W. $\operatorname{Li}^{1,2}$ and M. Alhousseini ${ }^{3}$ \\ ${ }^{1}$ University of Science and Technology Beijing, 100083, China \\ ${ }^{2}$ School of Energy and Environmental Engineering, China, badiedjourtefast@outlook.com \\ ${ }^{3}$ National Center for Solar Energy and Renewable Energy, CNESOLER, Mali
}

\section{$P A P E R \quad I N F O$}

\section{Paper history:}

Received 12 April 2018

Accepted in revised form 16 June 2018

\section{Keywords:}

Photovoltaic modules

Average power

Dust deposition

Surface cleaning

Optimal incline

\begin{abstract}
A B STRACT
The development of solar photovoltaic faces some difficulties in West African countries; such as: high cost of $\mathrm{kW} / \mathrm{h}$ produced and long duration of return on investment. To that, there are some installation and operation aspects of Photovoltaic(PV) modules. In terms of installation, the incline plays a predominant role in the efficiency of a field photovoltaic. Indeed, the modules being fixed, it is, therefore, necessary to find the right incline so that they can capture the most solar energy every day. In terms of operation, PV modules need to be exposed to outside in order to operate under the most possibility of direct sunlight. Such equipment is therefore subjected to a natural climatic condition causing a great impact on its performance. This article deals with the influence of the operating parameters (optimal tilt and dust deposits) of PV modules in view of their improvement in West African countries such as Mali. After the choice of the cleaning by cloth and the different inclines of the modules were studied; the experiments were developed during the months of April-May-June, 2017. The results showed a reduction of PV modules from 4 to $14 \%$ of their efficiency was due to the accumulation of dirt on their capture surface. In addition, this study reveals an impressive result: a simple cleaning can save us energy about $140 \mathrm{FCFA} / \mathrm{m}^{2} /$ month. Similarly, comparing with the outputs of the PV modules for different inclinations; it emerged that the optimal angle of inclination of the modules is slightly higher than the latitude of the study's place (about $15^{\circ}$ ).

doi: $10.5829 /$ ijee.2018.09.02.03
\end{abstract}

\section{INTRODUCTION}

Currently, the majority of the population of West Africa lives in small scattered villages. These countries have very low electrification rates; particularly in rural areas where electrification is not even exist. This fact is even one of the causes of the rural exodus and the massification of the big cities[1]. The rural electrification network is virtually non-existent, leaving the supply of decentralized mechanical and electrical energy (especially solar energy) the only choice available. In general, the possibilities of exploitation of these solar resources are promising; because these countries have abundant solar resources and they also have large places for the implementation of solar installations. The real life of the solar module performance status in these areas is very complicated and various. This is why any initiative in this sector must begin with a good knowledge of the environment and its dynamics. It must also take into account the climate and the different natural conditions[2].
Some investigations have indicated that climate conditions have an important effect on the yield of solar panels [2]-[7]. Moreover, studies by Boyle et al. [8]in Colorado, and by Hegazy[9] in Egypt, attracted to a build-up of dust substantially touches the efficacy of solar modules.

Several processes of yield improvement of solar modules have been proposed by Nazar[10]. Some studies have shown that the parameters such as the installation tilt[11], the prevailing wind direction, the site, pressure, viscosity of the surface and the time for which the modules are exposed in the environment, are connected to the density of dust accumulated on the surface of the modules[12, 13]. Likewise, Goossens and Van Kerschaever [14] have shown that elevated wind velocities can expand a build-up of dust on module surfaces.

Else studies on the impact of temperature variations on the particle deposit way on solar PV modules have been performed[15, 16]. Gholami et al.[12]gave a correlation between the density of the dust surface and the reduction of the transmission coefficient. 
Solar modules are subjected to an environment occasioning multiple sources of pollution and fouling. Among the most common, we can mention industrial pollutants, car pollution, acid rain, pollen, dust, sand, tree leaves, foam, mushrooms, marine salts, limestone and others. In addition, to driving their yields down, some pollutants can lead to premature wear of the modules by generating intense heating phenomena via the "hot spot" effect[17]. Under the effect of corrosion, aluminum profiles attack glazed protective surfaces. These then become rough and opaque, which therefore has a negative effect on the production yield $[5,18]$.

This article seeks to contribute to industrial innovation in the field of solar energy for a rational production and an efficient use of electric energy in West African countries. However, two fundamental aspects of the operation of PV modules deserve to be studied more precisely: dust deposits (very important in Sahelian climate), and the inclination of solar installation in these zones. This paperfocuses on investigations of a precise determination in terms of thecurrency of the energy losses generated by the dust deposits on the surface of the PV modules and an optimal inclination making it possible to maximize the production of energy of solar modules.A specificexperimentalstudy on optimal inclination to maximize production of energy modules in Mali and around is presented in the first section. The second section is dedicatedto an experimental investigation, particularly based in Mali, of dust deposits on the surface of PV modules.Finally, the paper presents aneconomic study on the cleaning of photovoltaic modules in this country.

Return on experience on the study of the influence of inclination and dust deposits on the performance of solar modules

Problematic of modules cleaning

Fouling of photovoltaic modules is a real obstacle to maintaining production performance; it is even the main reason for the decline in their yields.Table 1shows a bibliographic summary of module cleaning. A common solution to this problem is a manual and periodic cleaning of the installations by application of water. This usual method is certainly effective, but several disadvantages can however emerge:

i. A first problem concerns the waste of water; indeed, photovoltaic power stations (several hundreds of thousands of modules spread over a few hundred hectares) are regularly established in desert areas, thus promoting optimal sunshine. Unfortunately, such implantation zones have the disadvantage of accelerating the phenomena of fouling by sand and dust. Maintenance operations are therefore regular and require significant amounts of water for cooling and the complete cleaning of the plant, quantities of water that are rare in dry or desert areas. ii. Micro-scratches can appear over time on the surfaces after rubbing on sand grains. The consequences of these micro-scratches are radical since they can change the optical properties of the material, by modifying the reflection and transmission characteristics, particularly.

iii. Regular cleaning operations required to maintain the performance of PV modules can be expensive because it requires the intervention of a technical team to monitor the technical equipment for cleaning. This can significantly impact the economic depreciation period for the system.

\section{Natural disposal of dust}

Wind energy, gravitation and rainwater can contribute naturally to the cleaning of solar modules. This method often causes changes in position (vertical or oblique) of the solar cell array to remove dust. However, this rotation is very difficult or even impossible for large photovoltaic networks.

\subsubsection{Basic principle of cleaning with a cloth}

To clean the solar panels we need a bucket filled with soapy water, a dry cloth and a rubber squeegee. Wash carefully the surface of the panel with soap and a cloth to remove dust, debris and water stains. Then a squeegee is used to remove excess water. During cleaning, an inspection is made on the surface of the panels to detect cracks or parts at risk of detachment. This inspection will allow us to call the manufacturer or a technician in case of damage to the panel. The advantage of this method is that it is simple, less expensive and the disadvantage is that it is painful for large areas, significant use of water resources.

\section{Emerging technologies for cleaning solar modules}

In order to solve the problems related to the two previous methods and offer performance gains to solar modules some alternatives to conventional cleaning have emerged: the cleaning method based on the principle of photocatalysis and the method of cleaning by electrostatic field[19-22].

The main actor of the phenomenon of photocatalysis is the photocatalyst which, by definition, is a catalyst that is active under the action of light rays[23]. The photocatalyst, exposed under a light source, generates highly oxidizing molecules that react directly by oxidation-reduction with organic compounds or polluting gases (NOx) present on its surface to decompose them completely[23, 24].

In addition, to maintain correct operation of the photovoltaic system especially in entrenched locations and away from homes where maintenance is more difficult and especially where the lack of water is important, we can use the cleaning process by electrostatic field[25]. Dust particulates are drawn to solar modules because of electrostatic constraints. These 
dust particles thus loaded are finally subjected to repulsive electrostatic forces. However, the effect of rain on the earth makes the application of this method difficult[26].

\section{Robots for cleaning solar modules}

Robots mounted on rails along the modules, clean with a brush (and, or suck the dust) without using water[10, 27].They have the advantages of not using water, reduce maintenance costs, can clean a very large area in a short time and can be used in very remote places and at very high temperatures. The use of this method can make investment costs very high (a factor that may discourage their use, especially in West Africa).

\section{Self cleaning method}

Initially intended for space missions, it is a technique that uses an electrical charge that sends a wave repelling dust on the surface of the module. Effective in large installations, short execution time and reduction of maintenance costs but high costs of investment[28,29].

\section{Optimum tilt of solar modules}

In order to optimize the irradiation of the direct and diffuse radiation received by the sensors, better capture the sun and produce a maximum of energy, the inclination and the orientation of the solar panels are of enormous importance[33, 34].The electronically controlled tracking system and the periodic variation of the angle of inclination remain the methods used for the inclination of the solar panels.

The electronically controlled tracking system remains a expensive realization for increased efficiency and it is useful in days of light sky and useless when the sky is clouded over[35, 36]. In general, these systems can be less resistant to the Saharan environments under very hostile weather conditions, very frequent sandstorms with very high levels and temperature gradient that can easily damage the electronic controls.

The cheapest and most practical method is the periodic variation of the angle of inclination. In West African countries and more generally in the entire northern hemisphere, photovoltaic modules produce the maximum electricity with a southern orientation.

Practical evaluation of the effect of dust deposition and installation incline on the yield of photovoltaic modules

\section{Investigation place}

A landlocked and Sahelian country located at the belt of West Africa, Mali extends between the $10^{\text {th }}$ and $25^{\text {th }}$ degrees of north latitude and between the $4^{\text {th }}$ degree of longitude east and $12^{\text {th }}$ of longitude west and covers an area of 1,241,238 $\mathrm{km}^{2}$.It shares $7420 \mathrm{~km}$ of borders with 7 neighbouring countries: Algeria in the north, Niger and Burkina Faso in the east, Côte d'Ivoire, Guinea in the south, Mauritania, and Senegal in the west (Figure 1). The population, amounting to more than 18.9 million inhabitants in December 2017, is predominantly rural. The population density is 15.20 inhabitants per $\mathrm{km}^{2}$ and the annual population growth rate is about $3.36 \%$ per year [37]. An important rate of Malian population, mainly rural, lives in the absence of electricity. It is a sunny country: the average annual duration of sunstroke varies between 2700 hours in the extreme south and more than

TABLE 1 Bibliographic summary of module cleaning

\begin{tabular}{|c|c|c|c|c|}
\hline Cleaningprocesses & Description & Advantages & disadvantages & References \\
\hline $\begin{array}{l}\text { Basic principle of } \\
\text { cleaning with a } \\
\text { cloth }\end{array}$ & $\begin{array}{l}\text { Wash carefully the surface of } \\
\text { the panel with soap and a cloth } \\
\text { to remove dust, debris and } \\
\text { water stains }\end{array}$ & $\begin{array}{l}\text { Simple and less expensive; It can } \\
\text { avoid yield losses }\end{array}$ & $\begin{array}{l}\text { painful for large areas; } \\
\text { significant use of water } \\
\text { resources (especially in desert } \\
\text { areas);indirect degradation of } \\
\text { the surface of the modules } \\
\text { (appearance of micro-scratches } \\
\text { under the effects of friction) }\end{array}$ & {$[2,4,30,31]$} \\
\hline $\begin{array}{l}\text { Cleaning by } \\
\text { photocatalysis }\end{array}$ & $\begin{array}{l}\text { Applied in a single spray, It } \\
\text { reacts by oxidation-reduction } \\
\text { with organic compound or } \\
\text { polluting gas }\end{array}$ & $\begin{array}{l}\text { Makes solar panels completely } \\
\text { self-cleaning; Avoids yield losses; } \\
\text { reduces maintenance costs }\end{array}$ & $\begin{array}{c}\text { may present health risks because } \\
\text { of probable toxicity of } \\
\text { photocatalyst }\left(\mathrm{T}_{\mathrm{i}} \mathrm{O}_{2} \text { titanium }\right. \\
\text { dioxide })\end{array}$ & {$[19],[22]$} \\
\hline $\begin{array}{l}\text { Cleaning by } \\
\text { Electrostatc field }\end{array}$ & $\begin{array}{l}\text { Creation of repulsive } \\
\text { electrostatic forces between } \\
\text { dust particles and solar } \\
\text { modules }\end{array}$ & $\begin{array}{l}\text { Avoids yield losses; reduces } \\
\text { maintenance costs; used in } \\
\text { entrenched locations and away } \\
\text { from homes and where the lack of } \\
\text { water is important }\end{array}$ & $\begin{array}{l}\text { The effect of rain on the earth } \\
\text { makes the application of this } \\
\text { method difficult }\end{array}$ & $\begin{array}{l}{[20],[21],} \\
{[25],[26]}\end{array}$ \\
\hline $\begin{array}{l}\text { Cleaning by using } \\
\text { robots }\end{array}$ & $\begin{array}{l}\text { Robots clean with a brush (and, } \\
\text { or suck the dust) without using } \\
\text { any water. }\end{array}$ & $\begin{array}{l}\text { Clean a very large area in a short } \\
\text { time; can be used in very remote } \\
\text { places and at very high } \\
\text { temperatures; reduce maintenance } \\
\text { costs }\end{array}$ & Very high investment costs. & {$[10][32]$} \\
\hline $\begin{array}{l}\text { Self- } \\
\text { cleaningmethod }\end{array}$ & $\begin{array}{l}\text { use an electrical charge to send } \\
\text { a wave repelling dust. }\end{array}$ & $\begin{array}{c}\text { reduce maintenance costs; } \\
\text { effective in large installations; } \\
\text { short execution time }\end{array}$ & High costs of investment & {$[28][29]$} \\
\hline
\end{tabular}


3800 hours in the north of the country, in the desert, its geographical location allows a high potential of solar energy: this country has a very significant solar energy potential. The average sun's rays, correctly allocated on the national territory, is evaluated at $5-7 \mathrm{kWh} / \mathrm{m}^{2} /$ day with a quotidian sunlight period of 7 to 10 hours [38]. Solar installations are especially proper for providing electricity to populations in faraway and isolated zones. Unfortunately, the deposition of dust on PV modules and their poor orientation can reduce the power generated and cause degradation of PV performance.

Bamako (capital city of Mali)is located on the riversides of the Niger River and extends from west to east over 22 $\mathrm{km}$ and from north to south over $12 \mathrm{~km}$, covering an area of $267 \mathrm{~km}^{2}$.It is at Badalabougou, a district of Bamako, in the courtyard of the Faculty of Science and Technology (FST) that our present study was conducted.

The southern orientation is the best orientation in Mali (northern hemisphere) for a photovoltaic module. It is with this orientation that it will produce the maximum of electricity. The inclination of the modules being related to the latitude of the considered place hence an inclination around $12^{\circ}$ for the modules of Bamako and surroundings (the latitude of Bamako is $12^{\circ} 38^{\prime} 00$ "north).
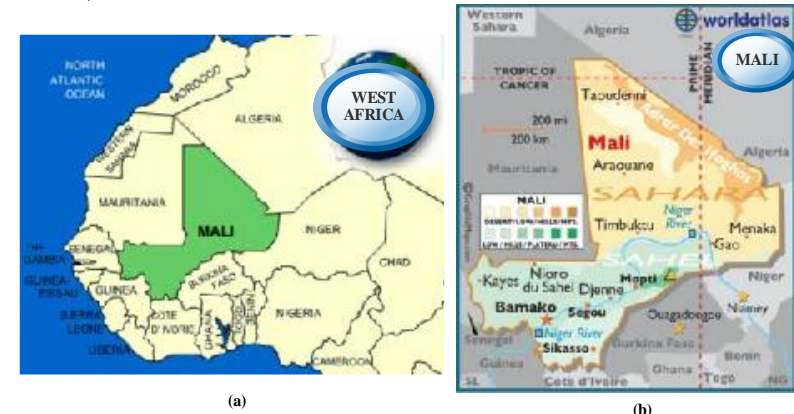

Figure 1. (a) West Africa Map and (b) Mali Map

\section{Experimental setup}

Experiments have been carried out to study the effect of dust deposition and the installation incline on the yield of PV panels. Measurements were made during periods (April-May-June) in 2017. Parameters such as illumination (Is) on the module plane, short circuit current (Icc) and open circuit voltage (OCV) have been measured.

For the study of the optimal tilt, two identical photovoltaic modules $(0.7 * 0.45 \mathrm{~m})$ were mounted on different supports facing south (Figure 2). The module $\mathrm{N}^{\circ} 1$ was, throughout the experiment, inclined at $15^{\circ}$ while the inclination of module $\mathrm{N}^{\circ} 2$ was varied $\left(0^{\circ}, 5^{\circ}\right.$, $10^{\circ}, 15^{\circ}, 17^{\circ}, 20^{\circ}$ and $25^{\circ}$ ).

And for the study of dust deposits, two identical photovoltaic modules $(1.40 * 0.70 \mathrm{~m})$ were mounted on different support inclined at $15^{\circ}$ and facing south. Module $\mathrm{N}^{\circ} 1$ was cleaned every morning with a volume of 2 litres of water each day while the module $\mathrm{N}^{\circ} 2$ was never cleaned during all the duration of the experiment (Figure 3).

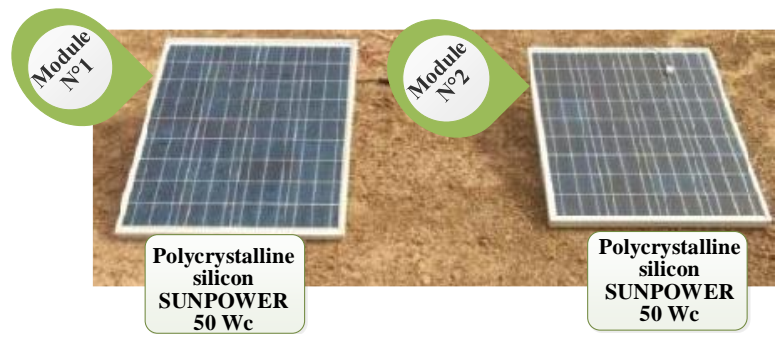

Figure 2. Study of Optimal Tilt: Experimental Setup

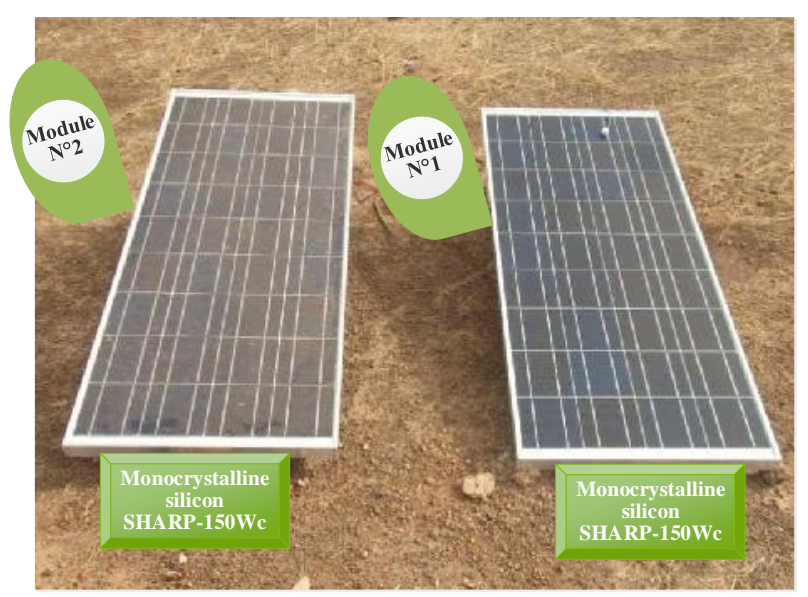

Figure 3. Study of Dust Deposit: Experimental Setup

The measurements were conducted in every day and inevery 2 hours between 8:00A.M.and4:00 P.M.

\section{Results}

\section{Study of the Optimal Tilt}

The choice of the optimal tilt of the solar panel is a very important step in the dimensioning of photovoltaic generators. The supports can be fixed or mobile with theoretical values of the angle of inclination, our study seeks to evaluate in comparison with various positions, the optimum inclination for a fixed support panel in a Sahelian climate.

The following table (Table 2) groups together the values of the daily average powers measured in Watt of the two photovoltaic modules and for the different values of the inclination of module $\mathrm{N}^{\circ} 2$, module $\mathrm{N}^{\circ} 1$ being fixed (15 ${ }^{\circ}$ ). Likewise, the table gives the quotidian average values of the open-circuit tension (Uco) and the shortcut current (Icc).

Comparing these daily average powers of different tilts (Figure 4), we note that with a tilt greater than $15^{\circ}$, the module becomes much less efficient. It loses even a large amount of energy compared to the module inclined at 15 . Moreover, with tilts less than $15^{\circ}$, the module remains 
TABLE 2 measurement results for different inclinations

\begin{tabular}{|c|c|c|c|c|c|c|}
\hline \multirow[b]{4}{*}{ Jour } & \multicolumn{3}{|l|}{ Module $\mathrm{N}^{\circ} 1$} & \multicolumn{3}{|l|}{ Module $\mathrm{N}^{\circ} 2$} \\
\hline & \multicolumn{6}{|c|}{ Tilt } \\
\hline & \multicolumn{3}{|l|}{$15^{\circ}$} & \multicolumn{3}{|l|}{$0^{\circ}$} \\
\hline & $\begin{array}{l}\text { Average short- } \\
\text { circuit current }(\mathrm{A})\end{array}$ & $\begin{array}{l}\text { Average open } \\
\text { circuit voltage }(\mathrm{V})\end{array}$ & $\begin{array}{l}\text { Average Power } \\
(\mathrm{W})\end{array}$ & $\begin{array}{l}\text { Average short- } \\
\text { circuit current (A) }\end{array}$ & $\begin{array}{l}\text { Average open } \\
\text { circuit voltage }(\mathrm{V})\end{array}$ & $\begin{array}{ll}\text { Average } & \text { Power } \\
\text { (W) } & \end{array}$ \\
\hline $24 / 04 / 2017$ & 2.57 & 18.89 & 48.5 & 2.64 & 18.37 & 47.5 \\
\hline $25 / 04 / 2017$ & 2.43 & 18.75 & 45.64 & 2.32 & 18.14 & 42.08 \\
\hline $26 / 04 / 2017$ & 2.42 & 18.78 & 45.45 & 2.26 & 18.50 & 41.81 \\
\hline $27 / 04 / 2017$ & 2.50 & 18.80 & 47 & 2.36 & 18.20 & 44 \\
\hline $28 / 04 / 2017$ & 2.60 & 18.84 & 49 & 2.29 & 18.5 & 43.5 \\
\hline \multicolumn{7}{|l|}{ Tilt } \\
\hline \multicolumn{4}{|l|}{$15^{\circ}$} & \multicolumn{3}{|l|}{$5^{\circ}$} \\
\hline $02 / 05 / 2017$ & 2.15 & 18.96 & 43 & 2.19 & 18.91 & 41.5 \\
\hline $03 / 05 / 2017$ & 2.58 & 18.98 & 49 & 2.54 & 18.90 & 48 \\
\hline $04 / 05 / 2017$ & 2.4 & 19.5 & 46.8 & 2.44 & 19.05 & 46.5 \\
\hline $05 / 05 / 2017$ & 2.55 & 19.02 & 48.5 & 2.55 & 19.02 & 48.5 \\
\hline $08 / 05 / 2017$ & 2.60 & 19.27 & 50 & 2.48 & 18.98 & 47 \\
\hline \multicolumn{7}{|c|}{ Tilt } \\
\hline \multicolumn{4}{|l|}{$15^{\circ}$} & \multicolumn{3}{|l|}{$10^{\circ}$} \\
\hline $09 / 05 / 2017$ & 2.57 & 18.89 & 48.5 & 2.5 & 18.80 & 47 \\
\hline $10 / 05 / 2017$ & 2.60 & 18.84 & 49 & 2.52 & 19.04 & 48 \\
\hline $11 / 05 / 2017$ & 2.44 & 19.27 & 47 & 2.31 & 19.74 & 45.6 \\
\hline $12 / 05 / 2017$ & 2.50 & 19.5 & 48.6 & 2.03 & 18.90 & 48 \\
\hline $15 / 05 / 2017$ & 2.60 & 19.02 & 49.5 & 2.77 & 19.02 & 48.5 \\
\hline & \multicolumn{3}{|l|}{ Module $\mathrm{N}^{\circ} 1$} & \multicolumn{3}{|l|}{ Module $\mathrm{N}^{\circ} 2$} \\
\hline & \multirow{2}{*}{\multicolumn{3}{|c|}{ Tilt }} & & & \\
\hline & & & & \multicolumn{3}{|l|}{$12^{\circ}$} \\
\hline Jour & $\begin{array}{l}\text { Average short- } \\
\text { circuit current (A) }\end{array}$ & $\begin{array}{l}\text { Average open } \\
\text { circuit voltage }(\mathrm{V})\end{array}$ & $\begin{array}{l}\text { Average Power } \\
(\mathrm{W})\end{array}$ & $\begin{array}{l}\text { Average short- } \\
\text { circuit current (A) }\end{array}$ & $\begin{array}{l}\text { Average open } \\
\text { circuit voltage }(\mathrm{V})\end{array}$ & $\begin{array}{ll}\begin{array}{l}\text { Average } \\
\text { (W) }\end{array} & \\
\end{array}$ \\
\hline $16 / 05 / 2017$ & 2.06 & 18.45 & 38 & 1.98 & 18.15 & 36 \\
\hline $17 / 05 / 2017$ & 2.10 & 19.05 & 40 & 1.97 & 19.24 & 38 \\
\hline $18 / 05 / 2017$ & 2.29 & 18.36 & 42 & 2.08 & 18.75 & 39 \\
\hline $19 / 05 / 2017$ & 2.24 & 18.98 & 42.5 & 2.16 & 18.50 & 40 \\
\hline $22 / 05 / 2017$ & 2.58 & 19.16 & 49.5 & 2.50 & 18.79 & 47 \\
\hline \multicolumn{7}{|l|}{ Tilt } \\
\hline \multicolumn{4}{|l|}{$15^{\circ}$} & \multicolumn{3}{|l|}{$17^{\circ}$} \\
\hline $23 / 05 / 2017$ & 2.39 & 19.06 & 45.5 & 2.21 & 19.01 & 42 \\
\hline $24 / 05 / 2017$ & 2.57 & 18.95 & 49 & 2.27 & 18.98 & 43 \\
\hline $25 / 05 / 2017$ & 2.43 & 18.90 & 46 & 2.10 & 19.02 & 40 \\
\hline $26 / 05 / 2017$ & 2.52 & 19.03 & 48 & 2.42 & 18.56 & 45 \\
\hline $30 / 05 / 2017$ & 2.22 & 18.89 & 42 & 2.15 & 19.05 & 40 \\
\hline \multicolumn{7}{|c|}{ Tilt } \\
\hline \multicolumn{4}{|l|}{$15^{\circ}$} & \multicolumn{3}{|l|}{$20^{\circ}$} \\
\hline $01 / 06 / 2017$ & 2.57 & 18.89 & 48.5 & 2.16 & 18.56 & 40 \\
\hline $02 / 06 / 2017$ & 2.42 & 19.02 & 46 & 2.16 & 18.96 & 41 \\
\hline $05 / 06 / 2017$ & 2.43 & 18.50 & 45 & 1.98 & 19.02 & 38 \\
\hline $06 / 06 / 2017$ & 2.39 & 18.70 & 44.6 & 2.05 & 18.98 & 39 \\
\hline $07 / 06 / 2017$ & 2.27 & 18.98 & 43 & 2.13 & 19.01 & 40.5 \\
\hline
\end{tabular}



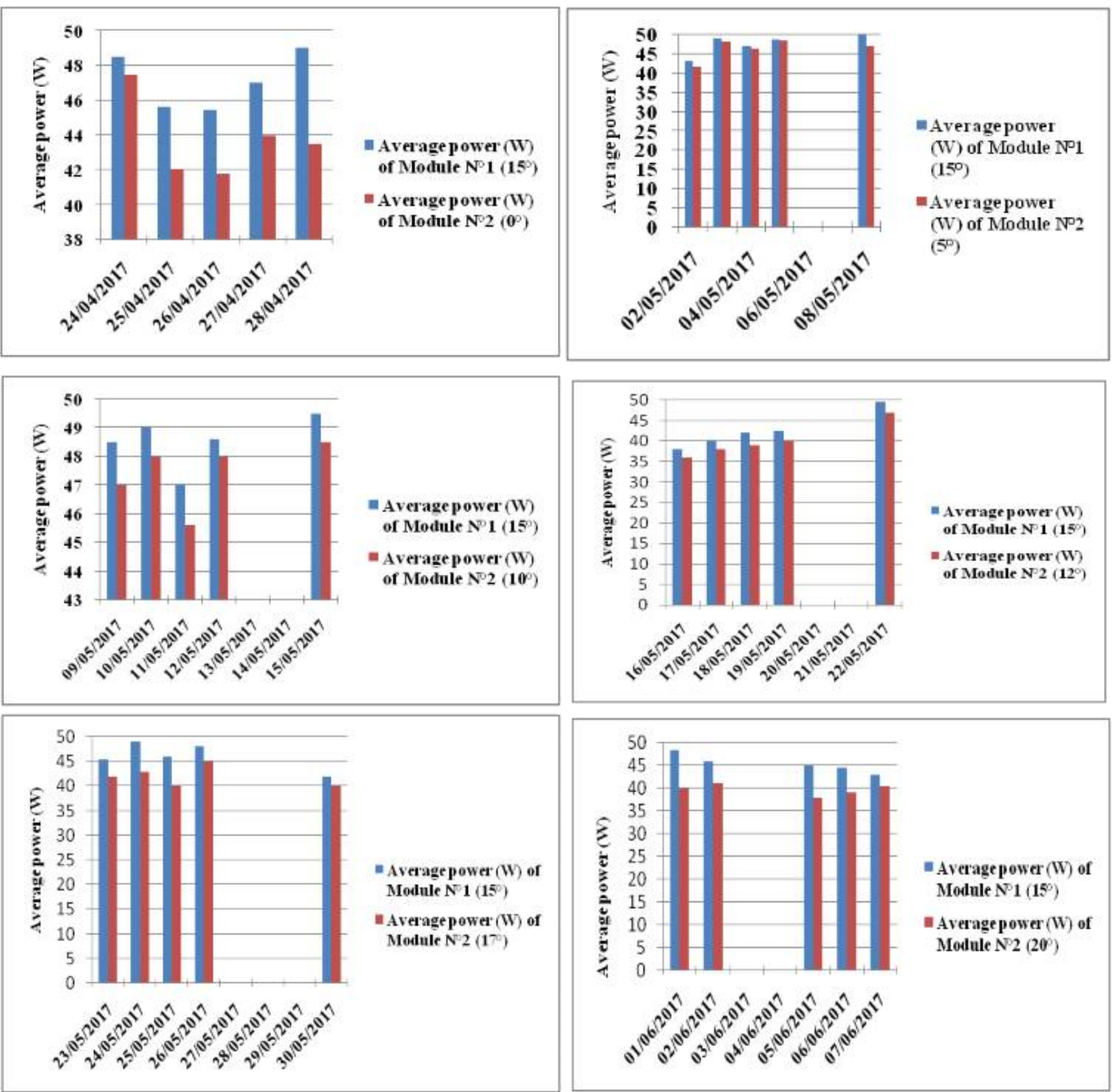

Figure 4. Evolution of daily average power for comparative study of optimal tilt

powerful but not like the $15^{\circ}$ inclined module. These results also indicate that with a tilt of $15^{\circ}$ the module is still more efficient than the theoretical tilt of the solar modules (the latitude of the place $\left(12^{\circ}\right)$ ). Experiences have shown that it is better to choose a slope slightly higher than that of the latitude of the place. We can then conclude that the optimal slope found during ourexperimental study is $15^{\circ}$ for our study area for thephotovoltaic modules mounted onthe fixed supports. 3.3.2 Study of Dust Deposits on Solar Modules

The two photovoltaic modules were mounted on different support inclined at $15^{\circ}$ and facing south. Module $\mathrm{N}^{\circ} 1$ was cleaned every morning while the module $\mathrm{N}^{\circ} 2$ was never cleaned during all the duration of the experiment. Table 3 gives us the daily averages powers of the two modules, the daily average power gains and the daily averages of the open-circuit voltage (Uco) and the short-circuit current (Icc).

In general terms, it has been found that the average power of the cleaned module was always the highest (Figure 5). This is because the cleaned module has received all of the sunlight on its surface and the uncleaned module has lost some of it. Moreover, it has been noticed that the average powers of the two modules are not regular; they are variable because the sunshine is not continuous and varies according to the moment.

According to this study, on the period of the experiment the simple cleaning with water, allowed us to 
have an average daily gain in power of $\mathbf{7 \%}$. Also during the entire period of the experiment, the energy gain of the cleaned module is $1667.8 \mathrm{Wh}$ compared to the uncleaned one. Either, with $0.980 \mathrm{~m}^{2}$ as a surface of the module, an average gain of the energy on the PV became $57 \mathrm{Wh} / \mathrm{m}^{2}$ per day or $1702 \mathrm{Wh} / \mathrm{m}^{2}$ per month.

However, the method used is certainly effective but consumes water which is another form of energy. A comparative study of gains is therefore necessary.

\section{Comparative study of gains}

TABLE 3. Daily Average Power of the two Solar Modules

\begin{tabular}{|c|c|c|c|c|}
\hline \multirow[b]{2}{*}{ Jour } & \multicolumn{2}{|c|}{ Daily average power (W) } & \multirow{2}{*}{$\begin{array}{c}\text { Daily } \\
\text { average } \\
\text { power } \\
\text { gain }(\%)\end{array}$} & \multirow{2}{*}{$\begin{array}{c}\text { Daily } \\
\text { Energy } \\
\text { Gain } \\
(\mathrm{Wh})\end{array}$} \\
\hline & $\begin{array}{c}\text { Module } \\
\mathrm{N}^{\circ} 1 \\
\text { (cleaned) }\end{array}$ & $\begin{array}{r}\text { Module } \mathrm{N}^{\circ} 2 \\
\text { (uncleaned) }\end{array}$ & & \\
\hline $24 / 04 / 2017$ & 98.30 & 92.20 & 6 & 48.8 \\
\hline $25 / 04 / 2017$ & 90.50 & 86.35 & 4.2 & 33.6 \\
\hline $26 / 04 / 2017$ & 82.15 & 74.60 & 7.6 & 60.8 \\
\hline $27 / 04 / 2017$ & 88.98 & 85.16 & 4 & 32 \\
\hline $28 / 04 / 2017$ & 95.16 & 87.25 & 8 & 64 \\
\hline 02/05/2017 & 96.85 & 92.64 & 5 & 40 \\
\hline 03/05/2017 & 96.17 & 92.34 & 4 & 32 \\
\hline 04/05/2017 & 96.33 & 91.87 & 4.5 & 36 \\
\hline $05 / 05 / 2017$ & 102.60 & 94.58 & 8 & 64 \\
\hline 08/05/2017 & 97.32 & 91.33 & 6 & 48 \\
\hline $09 / 05 / 2017$ & 102.37 & 95.57 & 7 & 56 \\
\hline $10 / 05 / 2017$ & 106.89 & 99.70 & 7 & 56 \\
\hline $11 / 05 / 2017$ & 101.50 & 89.45 & 12 & 96 \\
\hline $12 / 05 / 2017$ & 96.85 & 87.17 & 9 & 72 \\
\hline $15 / 05 / 2017$ & 93.47 & 86.50 & 7 & 56 \\
\hline $16 / 05 / 2017$ & 96.17 & 90.98 & 5.2 & 41.6 \\
\hline $17 / 05 / 2017$ & 102.30 & 94.41 & 8 & 64 \\
\hline $18 / 05 / 2017$ & 106.87 & 99.75 & 7 & 56 \\
\hline $19 / 05 / 2017$ & 118.30 & 104.50 & 14 & 112 \\
\hline $22 / 05 / 2017$ & 106.62 & 95.20 & 11.4 & 91.2 \\
\hline $23 / 05 / 2017$ & 98.98 & 88.75 & 10.2 & 81.6 \\
\hline $24 / 05 / 2017$ & 102.72 & 96.49 & 6.2 & 49.6 \\
\hline $25 / 05 / 2017$ & 106.15 & 98.75 & 7.4 & 59 \\
\hline $26 / 05 / 2017$ & 96.75 & 90.98 & 6 & 48 \\
\hline $30 / 05 / 2017$ & 102.33 & 92 & 10.3 & 82.4 \\
\hline $01 / 06 / 2017$ & 89.47 & 86.40 & 3.1 & 24.8 \\
\hline $02 / 06 / 2017$ & 82.04 & 75.90 & 6.1 & 48.8 \\
\hline $05 / 06 / 2017$ & 89.50 & 87 & 3 & 24 \\
\hline 06/06/2017 & 96.04 & 91.23 & 5 & 40 \\
\hline $07 / 06 / 2017$ & 96.85 & 90.64 & 6.2 & 49.6 \\
\hline \multicolumn{3}{|c|}{ Over the period of the experiment } & $7 \%$ & 1667.8 \\
\hline
\end{tabular}

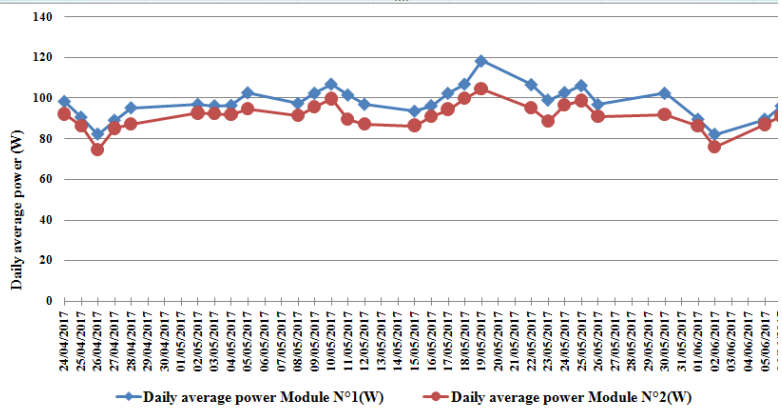

Figure 5. Evolution of the Daily Average Power of the two Solar Modules
For a comprehensive comparative study, we felt it necessary to estimate the cost of cleaning in order to appreciate a net economic gain:

$\mathrm{C}_{\mathrm{c}}=\mathrm{Q}_{\mathrm{cw}}+\mathrm{M}_{\mathrm{pc}}+\mathrm{S}_{\mathrm{c}}$

with:

$\mathrm{C}_{\mathrm{c}}$ :the cost of cleaning;

$\mathrm{Q}_{\mathrm{cw}}$ :the price of water used;

$\mathrm{M}_{\mathrm{pc}}$ :the manpower for the cleaning;

$\mathrm{S}_{\mathrm{c}}$ :the price of soap for the cleaning of our module.

In Mali, the price of a cubic meter of water is about 1200 CFA Franc and with 2 litres of water $\left(0.002 \mathrm{~m}^{3}\right)$ each day to clean the module $\mathrm{N}^{\circ} 1$ then the price of water needed for the cleaning of one square meter per day will then $\mathrm{beQ}_{\mathrm{cw}}=74 \mathrm{CFA}$ Franc per month; the manpower for the cleaning of an area of $5000 \mathrm{~m}^{2}$ can be estimated at 1500 CFA Franc per day. Either an expense for cleaning $M_{p c}=$ $9 \mathrm{CFA}$ Franc $/ \mathrm{m}^{2} /$ month. On the other hand we used, per day, 75CFA Franc of soap powder to clean our module. Which corresponds to $S_{c}=75$ CFA Franc of soap.

However, the cost of cleaning is estimated at $158 \mathrm{CFA}$ Franc $/ \mathrm{m}^{2} /$ month.

The gross economic gain is the product of the energy gain by the price of the $\mathrm{kWh}$ produced. Suppose that the price of solar $\mathrm{kWh}$ in Mali is estimated at about 175 CFA Franc, the gross economic gain will then be 297.85 CFA Franc $/ \mathrm{m}^{2} /$ month

The net economic gain which is the difference between the gross economic gain and the cost of cleaning the modules is then $140 \mathrm{FCFA} / \mathrm{m}^{2} / \mathrm{month}$.

Thus we can, by simply cleaning our PV modules with water, make a net gain of 140 CFA Franc $/ \mathrm{m}^{2} /$ month. This saving of profit can increase if other more modern methods of cleaning are used.

\section{CONCLUSION}

Photovoltaic installations must operate at their maximum rated capacity to ensure constant and reliable power. To function optimally, the solar panels must stabilize their temperature around $20^{\circ} \mathrm{C}$, but also remain clean[39]. In fact, a cleaned surface and an optimal inclination allow the sensors to receive a maximum of solar rays, which guarantees a better efficiency of the installation. It is therefore important to keep the solar panels clean and to maintain them regularly. The long life of solar modules also depends on their maintenance.

In this study, an experimental investigation was conducted to evaluate the influence of installation tilt and dust deposits on the performance of photovoltaic panels. The non-cleaning of the solar modules made us lose about $7 \%$ of its performance and this loss leads to the decrease of the energy production indicated by the manufacturers. A simple cleaning of our photovoltaic systems with soapy water allows us to save energy. 
Considering the cost of cleaning our module, our study reveals a net gain of $140 \mathrm{CFA}$ Franc $/ \mathrm{m}^{2} /$ month.

Additional study on the inclination of the modules allowed us to confirm that the optimum angle of the PV modules is close to the latitude of the place. With regard to our study area (Bamako) which at a latitude of $12^{\circ} 38^{\prime}$, we obtained $15^{\circ}$ as the optimum angle for the different inclinations of the modules. Power losses are greater if we exceed $15^{\circ}$.

Given the influences of these parameters, it would be interesting to continue this study by redoing the study over a long period, using other cleaning methodsandsearching for the ideal incline for throughout the year.

\section{REFERENCES}

1. M. Segmani, T. Lecoq, N. H. Dezfouli, A. Diawara, and L. E. Renouvelables, 2007, MALIDEAL Projet «Plateforme Solaire au Mali ».

2. A. Gholami, I. Khazaee, S. Eslami, M. Zandi, and E. Akrami, 2018, "Experimental investigation of dust deposition e ff ects on photo-voltaic output performance," Sol. Energy, vol. 159, no. November 2017, pp. 346-352.

3. M. Abderrezek and M. Fathi, 2017, "Experimental study of the dust effect on photovoltaic panels ' energy yield," Sol. Energy, vol. 142, pp. 308-320.

4. B. R. Paudyal and S. R. Shakya, 2016, "Dust accumulation effects on efficiency of solar PV modules for off grid purpose: A case study of Kathmandu," Sol. Energy, vol. 135, pp. 103-110.

5. M. Mani and R. Pillai, 2010, "Impact of dust on solar photovoltaic ( PV ) performance: Research status, challenges and recommendations," Renew. Sustain. Energy Rev., vol. 14, no. 9, pp. 3124-3131.

6. A. Rao, R. Pillai, M. Mani, and P. Ramamurthy, 2014 , "Influence of dust deposition on photovoltaic panel performance,” Energy Procedia, vol. 54, pp. 690-700.

7. F. Mejia, J. Kleissl, and J. L. Bosch, 2014, "The effect of dust on solar photovoltaic systems," Energy Procedia, vol. 49, pp. 2370-2376.

8. L. Boyle, H. Flinchpaugh, and M. P. Hannigan, 2015, "Natural soiling of photovoltaic cover plates and the impact on transmission," Renew. Energy, vol. 77, p. 237.e1-237.e8.

9. A. A. Hegazy, 2001, "Effect of dust accumulation on solar transmittance through glass covers of plate-type collectors," Renew. Energy, vol. 22, pp. 525-540.

10. R. Nazar, 2015, "Improvement of Efficiency of Solar Panel Using Different Methods .," Int. J. Electr. Electron. Eng., vol. 7, no. 1, pp. 12-17,

11. P. K. Das, M. A. Habib, and M. Mynuddin, 2015, "Microcontroller Based Automatic Solar Tracking System with Mirror Booster," Int. J. Sustain. Green Energy, vol. 4, no. 4, pp. 125-136.

12. A. Gholami, A. Saboonchi, and A. A. Alemrajabi, 2017, "Experimental Study of Factors Affecting dust accumulation and their effects on the transmission coefficient of glass for solar applications," Renew. Energy.

13. M. J. Adinoyi and S. A. M. Said, 2013, "Effect of dust accumulation on the power outputs of solar photovoltaic modules," Renew. Energy, vol. 60, pp. 633-636.

14. D. Goossens and E. V. A. N. Kerschaever, 1999, "Aeolian Dust Deposition on photovoltaic Solar Cells: the Effects of Wind Velocity and Airborne Dust Concentration on Cell Performance," Pergamon, vol. 66, no. 4, pp. 277-289.

15. A. Al Shehri, B. Parrott, P. Carrasco, H. Al Saiari, and I. Taie, 2017, "Accelerated testbed for studying the wear, optical and electrical characteristics of dry cleaned PV solar panels," Sol. Energy, vol. 146, pp. 8-19.

16. Y. Jiang and L. Lu, 2016, "Experimentally Investigating the Effect of Temperature Differences in the Particle Deposition Process on Solar Photovoltaic ( PV ) Modules," Sustainability.

17. T. V Ramachandra, R. Jain, and G. Krishnadas, 2011, "Hotspots of solar potential in India," Renew. Sustain. Energy Rev., vol. 15, no. 6, pp. 3178-3186.

18. J. P. Bock, J. R. Robison, R. Sharma, J. Zhang, and M. K. Mazumder, 2008, "An Efficient Power Management Approach for Self-Cleaning Solar Panels with Integrated Electrodynamic Screens," in Proc. ESA Annual Meeting on Electrostatics.

19. R. Greenough, D. Jensen, and E. Voss, 2016, "Project SPACE : Solar Panel Automated Cleaning Environment," Santa Clara University Scholar Commons.

20. S. Patil and H. M. MALLARADHYA, 2016, "Design and Implementation of Microcontroller Based," Int. J. Eng. Res. Adv. Technol., vol. 2, no. 1.

21. A. K. Mondal and K. Bansal, 2015, "A brief history and future aspects in automatic cleaning systems for solar photovoltaic panels," Adv. Robot., no. May, pp. 37-41,

22. R. G. Padaki, 2016, "Self-Cleaning Technology for solar PV Panel 1,” Int. J. Sci. Dev. Res., vol. 1, no. 9.

23. "http://fr.wikipedia.org/wiki/Photocatalyse," http://fr.wikipedia.org/wiki/Photocatalyse, 2017.

24. "Dépollution par photocatalyse _ un procédé d'avenir," http://www.actuenvironnement.com/ae/news/depollution_photocatalyse_ 6819.php4.

25. H. Kawamoto and T. Shibata, 2015, "Electrostatic cleaning system for removal of sand from solar panels," J. Electrostat., vol. 73, pp. 65-70,

26. A. Mishra and A. Sarathe, 2017, "Study of Solar Panel Cleaning System to Enhance the Performance of Solar," J. Emerg. Technol. Innov. Res., vol. 4, no. 9, pp. 84-89,.

27. "Rapid-cleaning robots set to cut solar energy losses, labor costs," http://analysis.newenergyupdate.com/pvinsider/rapid-cleaning-robots-set-cut-solar-energy-losseslabor-costs, 2017.

28. Y. A. Salam, T. Green, and Y. T. Lin, 2014, "Automated Self-Cleaning Solar Panel,"

29. "Self-Cleaning System Boosts Efficiency of Solar Panels," http://www.bu.edu/today/2014/self-cleaning-systemboosts-efficiency-of-solar-panels, 2014. . 
30. H. A. Kazem and M. T. Chaichan, 2016, "Experimental analysis of the effect of dust' $s$ physical properties on photovoltaic modules in Northern Oman," Sol. Energy, vol. 139 , pp. $68-80$,

31. M. T. Chaichan, B. A. Mohammed, and H. A. Kazem, 2015, "Effect of pollution and cleaning on photovoltaic performance based on experimental study," Int. J. Sci. Eng. Res., vol. 6, no. 4,.

32. "construction-australias-first-commercial-csp-plant-startmid-2018," http://analysis.newenergyupdate.com/, 2018.

33. D. H. W. Li and T. N. T. Lam, 2007, "Determining the Optimum Tilt Angle and Orientation for Solar Energy Collection Based on Measured Solar Radiance Data," Int. J. Photoenergy, vol. 2007.

34. O. Asowata, J. Swart, C. Pienaar, and R. Schoeman, 1900, "Optimum tilt and orientation angles for photovoltaic panels in the Vaal Triangle," pp. 0-1.
35. M. Koussa, M. Haddadi, D. Saheb, A. Malek, and S. Hadji, 2012, "Sun tracker systems effects on flat plate photovoltaic PV systems performance for different sky states: A case of an arid and hot climate .," Energy Procedia, vol. 18, pp. 839-850.

36. S. Abdallah, 2004, "The effect of using sun tracking systems on the voltage - current characteristics and power generation of flat plate photovoltaics," Energy Convers. Manag., vol. 45, pp. 1671-1679.

37. "Mali , Fiche pays, 2017, PopulationData," https://www.populationdata.net/pays/mali/,. .

38. G. de la B. 2015, africaine de Développement, "Les énergies renouvelables en Afrique : Profil pays du Mali," Groupe la Banq. africaine développement,

39. R. Gaughan, 2017, "How Does Temperature Affect Solar Panels," Sciencing,.

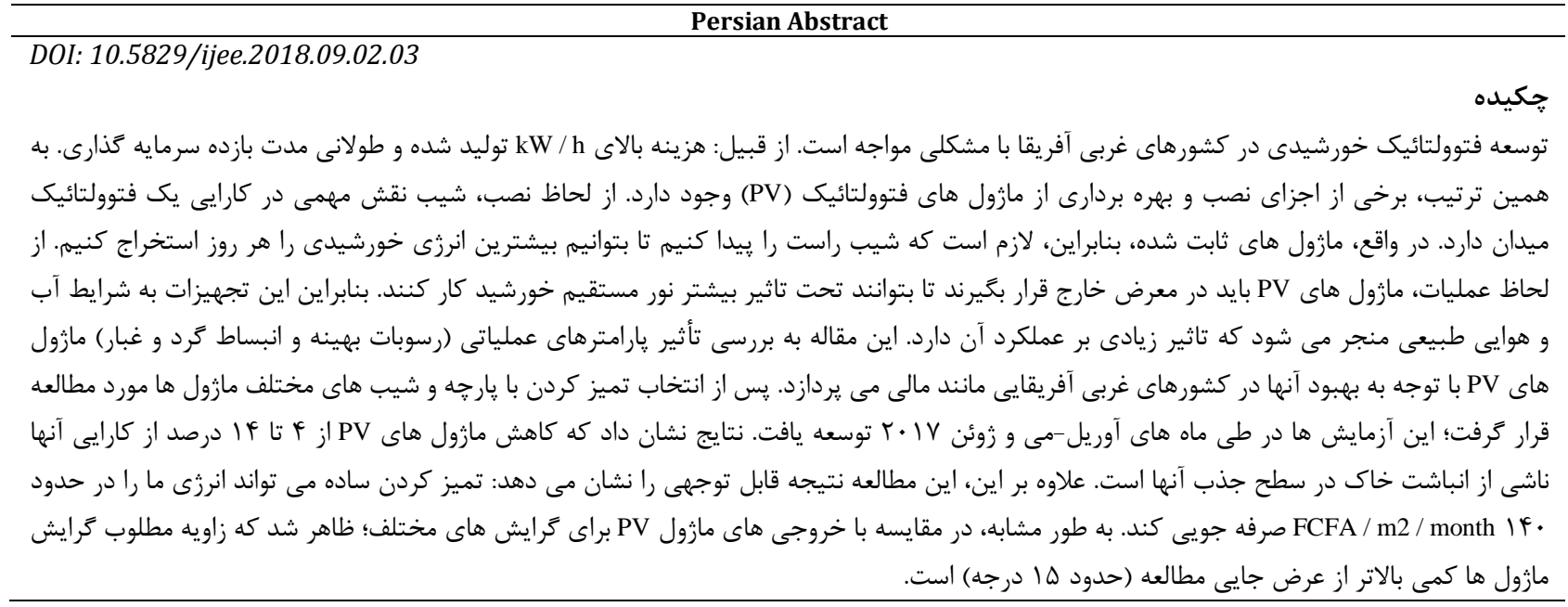

